\title{
Horticultural science-a century of discovery and application
}

Article

Accepted Version

Dixon, G. R. (2019) Horticultural science-a century of discovery and application. Journal of Horticultural Science and Biotechnology, 94 (5). pp. 550-572. ISSN 1462-0316 doi: https://doi.org/10.1080/14620316.2019.1599700 Available at https://centaur.reading.ac.uk/84938/

It is advisable to refer to the publisher's version if you intend to cite from the work. See Guidance on citing.

To link to this article DOI: http://dx.doi.org/10.1080/14620316.2019.1599700

Publisher: Taylor \& Francis

All outputs in CentAUR are protected by Intellectual Property Rights law, including copyright law. Copyright and IPR is retained by the creators or other copyright holders. Terms and conditions for use of this material are defined in the End User Agreement.

\section{www.reading.ac.uk/centaur}

\section{CentAUR}

Central Archive at the University of Reading

Reading's research outputs online 


\section{Horticultural science-a century of discovery and application}

G R Dixon, School of Agriculture, Policy and Development, Earley Gate, University of Reading, Reading, Berkshire RG6 6AR, United Kingdom

geoffrdixon@gmail.com

\section{Abstract}

The Journal of Horticultural Science and Biotechnology (JHSB) celebrates, in 2019, a century of continuously publishing peer-review, research-based articles and reviews. Since 1919 scientific discoveries and their application through subsequently evolved industrial technologies have formed the basis for enormous advances and changes in the production of fruit, vegetables and ornamentals. New industries have been founded and expanded as a result of scientific discoveries. Science has brought greater precision, predictability and reliability into horticultural crop production raising the quality and range of products available for consumers. Market forces themselves have imposed vast change in the manner by which horticultural products are produced and sold altering the industrial structures. Horticultural industries have coped with and thrived on these changes because of their swift and effective adoption of discoveries in horticultural science which in turn has driven the need for more research in a cyclic process.

This review follows, through a selection of articles published in JHSB, the evolution of aspects of horticultural science and identifies how change has influenced crops and their production. Topics considered of particular prominence in the evolution of horticultural science include: pollination, fertility and compatibility; roots and rootstocks; growth regulation and plant propagation; breeding and nomenclature; nutrition; crop protection; cultivation and management; interactions between environment and growth; water-use efficiency; storage; and environment and social welfare. The history of change in horticultural science and the industries which it serves is contained within the articles selected. They demonstrate the 
successful manner in which JHSB has fulfilled the aspirations of its founders for a sciencebased journal which offers new ideas for industry. It has survived through one-hundred years vindicating the founders' aspirations. This review does not rigorously dissect and analyse each individual aspect of horticultural science used in charting the history of JHSB's academic voyage. It uses them as signposts showing avenues of new and developing knowledge and scholarship also identifying where discoveries have resulted in industrial progress.

Key words: horticultural science, discovery, application, industrial progress, centenary

\section{Introduction}

Horticultural science makes significant and substantial discoveries. Many of these, when translated into technologies, have either under-pinned new commercial processes or founded entire industries. Research published in the Journal of Horticultural Science and Biotechnology (JHSB) and in its preceding titles (Journal of Pomology, Journal of Pomology and Horticultural Science and Journal of Horticultural Science) charts the history of these discoveries. This review outlines aspects of horticultural science's evolution from the perspective of publications in JHSB over its one-hundred years history. In this period sciencebased explanations have replaced observational perceptions. Horticultural science is an applied biological discipline and its research-driven advances are discussed here in the context of industrial improvement. Detailed reviews of specific biological topics are discussed by researchers elsewhere in JHSB and other journals.

\section{Pollination, fertilisation, compatibility}

Understanding why some top fruit cultivars form viable fruit only when planted in close proximity with particular partners permits more rational orchard planning. The first paper in the Journal of Pomology described tests of self-sterility in plums, cherries and apples (Sutton 1919). She showed that some cultivars require an exchange of pollen from specific donors. 
Self-sterile apple cultivars required "pollinisers" planted alongside them. In stone fruit it seemed that provided a cultivar produced ample pollen and flowered simultaneously with a partner most donors sufficed. Crane (1922) and Crane \& Lawrence (1928) however, produced more detailed and rigorous studies identifying specific cross-incompatibility groups for cherries and plums. These authors explained sterility in terms of three groupings:

- firstly, generational sterility referring to the normal processes in the alternation of generations and the development of pollen, embryo sac, embryo and endosperm and the relation of these organs with each other;

- secondly, morphological sterility due to the suppression or abortion of the sex organs;

- thirdly, incompatibility, this is not strictly sterility since both the pollen and the ovules are still functional.

Failures in fruit setting result from self- and cross-incompatible pollinations which cause an absence of fertilisation with the pollen tubes being arrested in the nutrient stylar tissue. Compatible pollinations resulted from pollen tubes penetrating the full length of the style and the male and female nuclei fusing and allowing development of fertilised ovaries into fruit. This research founded the identification of the compatibility groupings used in horticultural practice for all pip and stone temperate fruit cultivars.

In the tropics, field experiments with cacao in Trinidad identified three clonal groups which consistently produced high and low yields of wet cacao (Dodds and Cope, 1961). Later, as explanation, Lockwood (1977) identified cross-incompatibility in cocoa grown in Ghana. His work identified compatibility and incompatibility in seed raised cocoa plants. Self-compatible strains cropped earlier than incompatible ones of similar progeny. In olives, a warm temperate crop, failed sexual compatibility within and between cultivars results when pollen tube growth decreases between the stigma and upper style and between the upper style and lower style (Wu 
et al., 2002). This research showed that there are varying degrees of compatibility and selfincompatibility in olives with cv. 'Frantoio' being an effective general pollinator. Further clarity in understanding the genetic characteristics controlling pollination and fertilisation appeared in the 1990s when genes controlling sterility (S-genes) were identified. Matsumoto et al (2003) for example, studied several apple genotypes and identified that the cv. 'Dolgo' did not contain any known sterility S-RNases encoded at the S-locus suggesting its usefulness as a universal pollinator for most apple cultivars.

Understanding sterility and compatibility between fruit cultivars brought logic and clarity into orchard planning and subsequent crop sequencing. Defining these traits in molecular terms now offers opportunities for developing cultivars where these barriers have been removed and breeders can concentrate on improving fruit quality and increasing its value in consumers' diets.

\section{Roots and rootstocks}

Grafting and budding rootstocks with favoured scions in pip and stone fruit is one of pomologists' oldest skills. Knowledge based on observed successes or failures was passed between nurserymen over millennia. The origins of 'Paradise' apple rootstocks used commercially in Europe and the Near East for several centuries, were reviewed in detail by Bunyard (1919). In practice these stocks lacked reliability and effectiveness. The research which eventually resolved these problems resulted in the development of Malling IX, a very dwarfing rootstock derived from the French cv. 'Jaune de Metz' and was recorded by Hatton

(1920). Probably, this has become the most widely used rootstock in current apple orchards worldwide. Dwarfing rootstocks, Hatton (1920) considered, were of two types, true dwarfing forms which root poorly and more vigorous but still dwarfing types. Team work reported by Amos et al., (1930) defined relationships between scions and stocks particularly for stem- 
worked apples. In a maiden year, the weight of roots was identified as a characteristic of the stock rather than the scion. Subsequently, however, the effect of the scion on total root volume becomes more marked; for example, cv. 'Grenadier' scions induce larger root systems than some other cultivars. Large roots types bear a lesser percentage of fibrous roots compared with smaller ones in similar circumstances. Scions may influence the size of the aerial and edaphic tree systems but rootstocks still dominate the overall relationship.

Rootstock research is a long-term process as exemplified by Hatton (1936). His report identified how rootstocks influence fruit formation using a comparison of Malling IX and Malling IV. Rootstock effects were assessed by measuring branch and stem (trunk) weight. When grafted on to Malling IX one cultivar produced 7.5 times its own weight of fruit. Rootstocks it was found affected: scion leaf area, growth types, fruit bud formation and position, percentage of blossom setting, time of blossoming, fruit colour, storage quality and rot resistance, chemical composition of fruit, disease resistance or susceptibility and physiological disorders in the orchard.

Anatomical relationships between stocks and scions grafted in compatible and incompatible combinations of temperate hardy fruit trees were reported by Herrero (1951). Disturbance and destruction of the cambial meristem between stock and scion results in the formation of a layer of undifferentiated tissue. Marked differences developed in starch distribution in parts of the graft union resulting in restricted growth, poor functioning of leaves and early defoliation accompanied by premature degeneration of the phloem in stone fruit such as plums and peaches.

Fifteen years research with 27 Malling-Merton apple rootstocks with scions of the cvs. 'Cox's Orange Pippin', 'Jonathon' and 'Ellison's Orange' as scions are reported by Preston (1966). The Malling-Merton clones were bred for resistance against woolly aphis (Eriosoma 
lanigerum). Most clones arose from a cross between cv. 'Northern Spy' and a selection of Malling rootstocks and the progeny were propagated clonally. Rootstock performance stabilised after 15 years. None of the Malling-Merton clones produced trees as small as those combinations where Malling IX was used. For English conditions MM104, MM106, MM111 and M25 were considered suitable and elsewhere MM 101, MM103, MM110, MM115 and MM 116 were advocated. Recently, Sun et al (2014) identified that rootstocks influence precocity, tree size, fruit quality, yield efficiency and mineral uptake and capabilities for withstanding adverse environmental conditions.

Research based studies of rootstocks and their relations with scion cultivars provided nursery industry with reliable and identified propagation material. Fruit growers benefited by the control of fruit tree size enabling increasing intensification of top fruit production thereby making more reliable and profitable use of suitable land.

\section{Growth regulation and plant propagation}

Controlling orchard events such as pre-harvest fruit drop demanded an understanding of the source and properties of growth regulators. Initially, research consisted of spraying trees with known growth regulators such as naphthalene acetic acid (NAA) (Vyvyan, 1946). Yields of apple cvs. 'Beauty of Bath', 'Miller's Seedling' and 'Worcester Pearmain' increased following spraying when fruit drop was imminent.

Understanding the reasons why growth regulators produced these effects demanded detailed studies of biochemistry, physiology and anatomy using artificially prepared compounds; naturally produced materials were isolated with difficulty and then only available in minute amounts. The preparation and study of growth regulating substances by Osborne \& Wain (1951) identified how synthetic plant growth regulating substances induced morphogenic responses in tomato plants. Applications of aryloxyaliphatic acid compounds produced 
epinasty and morphogenic responses, compounds such as: 2,3,5 triiodobenzoic acid (TIB) and alpha (2 nathoxy) phenylacetic acid (NPA) caused Frenching (loss of the apical bud with proliferation of lateral growths), fasciation of leaves and malformed development of inflorescences in the terminal position. Subsequently, Osborne et al., (1952) formulated synthetic growth regulating chemicals which promoted the rooting of privet (Ligustrum spp.) cuttings and tomato leaves, and induced seedless development of tomato fruits. Research demonstrated that growth-regulating properties are associated with chemical structure. The relevance of these findings for fruit culture were established by Luckwill (1953). He identified why the development of fertilised seeds in apples stimulated the release of further growth regulating molecules which in turn encouraged fruit swelling.

Direct spraying of growth regulating chemicals continues as a useful technique for fruit production. Analyses of development of sweet cherry fruit treated with gibberellic acid $\left(\mathrm{GA}_{3}\right)$ for example, provided increased understanding of fruit growth, firmness and cell hydrolytic enzyme activity (Choi et al 2002) showing that cherry fruit develop in three distinct phases viz: cell division, lag phase and enlargement. Gibberellic acid $\left(\mathrm{GA}_{3}\right)$ applications reduced the rate of softening and onset of ripening in the late season cultivars but had little effect on early season types. Other crops also benefitted from this approach. Uneven ripening in 'Bangalore Blue' grape (Vitis vinifera $\mathrm{x}$ Vitis labrusca) berries in India is a substantial problem and has been linked to variations in seed viability (Shivashankar et al 2017). Spraying GA 3 onto immature berries reduced the incidence of this problem.

Paradoxically, inhibition of gibberellin biosynthesis also has a role in orchard management. Studies using Apogee ${ }^{\circledR}(27.5 \%(\mathrm{w} / \mathrm{w})$ prohexadione-calcium, a cyclohexanetrione), applied to cv. 'Bartlett' pears, controlled shoot proliferation (Southwick et al 2004) without deleterious effects on return blooming, fruit size or quality, soluble solids or yields. 
Enhanced laboratory technology brought opportunities for studying plant growth regulator metabolism in ever more refined detail. As a result, another novel class of plant growth regulators, the jasmonates, has been identified. These compounds regulate storage organ formation, resistance to biotic and abiotic stresses, growth inhibition in tissues in roots, and young shoots and interact with other plant growth regulators such as ethylene (Rohwer \& Erwin, 2008). Studies using the laboratory model plant, Arabidopsis thaliana, (rock cress) demonstrated that jasmonates encourage systemic acquired resistance (SAR) towards pathogens and influence pest and predator relationships.

Knowledge of the mechanisms of plant growth regulation yielded means for the micro-culture and tissue culture of horticultural crop species. By the mid-1970s micro-propagation was well established as a valuable technique for the multiplication of soft and top fruit. Boxus (1974) for example, reported on the micropropagation of strawberry with media containing the cytokinin-like growth regulator, 6-benzylaminopurine. This work demonstrated the importance of cytokinins in root formation and permitted the massive and speedy propagation of strawberry plants. The technique was capable of propagating 25 million plants clonally from a single mother plant. It offered opportunities for the industrialisation of strawberry cultivar propagation provided plant health and uniform stability were safeguarded. Similarly, propagation in vitro of M26 apple rootstocks using standardised Murashige \& Skoog (1962) media permitted the production of an estimated 60,000 shoots in 8 months which rooted and weaned readily without mutations or abnormalities (Jones et al 1977). Perfecting the in vitro propagation of other woody subjects took longer requiring more specialised media such as those of Quoirin and Lepoivre (1977). Using this media for cold hardy, dwarfing and semidwarfing rootstocks avoided shoot tip necrosis and hyperhydricity (Sun et al 2014).

Micro-propagation expanded commercially particularly into the propagation of ornamental subjects such as lily (Lilium spp.). Here use of filament tissue permitted successful callus 
initiation, maintenance and plantlet regeneration ( $\mathrm{Du}$ et al 2014). The usefulness of callus induction and plant regeneration now makes in vitro propagation a standard tool for genetic studies; as reported for lateral shoots of herbaceous bamboo Mniochloa abersend by Zanf et al (2017). Another large application is developing disease-tested clones. For example, Mazri (2014) reported the effects of plant growth regulators and carbon sources on shoot proliferation and regeneration in date palm (Phoenix dactylifera ) '16-bis'. Date palm propagation enabled the replanting of Moroccan groves damaged by bayoud disease caused by Fusarium oxysporum f sp albedinis. Micro-propagation also has value for conserving populations of endangered species such as Sternbergia clusiana (Amaryllidaceae). Diminishing populations of this vulnerable but medicinally valuable plant, are found in Jordan and neighbouring countries. The efficient, rapid, vegetative propagation of $S$. clusiana safeguards these populations while allowing domestication for medical purposes as described by Oran \& Fattash (2005).

Rapid methods for macro-asexual vegetative propagation retain their importance especially for some ornamental bulbous crops and were exploited in the late 1980s for the production of virus-tested Narcissus bulbs. The techniques of twin scaling and chipping are applicable for daffodil (Narcissus spp.) crops. In year-one bulbils derived from chipping produced the highest weight gains compared with twin scaling; there was a linear relationship between propagule size and bulbil weight reported Fenlon et al (1990). Conventional propagation systems are also still applicable for some tropical plants as noted by Raji \& Siril (2016) working with the Ceylon olive (Elaeocarpus serratus). This is an under-utilised edible fruit tree that is sparsely distributed in the southern peninsula of the Indian sub-continent. Propagation based on softwood cuttings facilitates moderate-scale cloning of valuable, elite germplasm.

Understanding plant growth regulation and its chemistry brought new opportunities for orchard culture, the development of mass propagation industries, widespread abilities for rooting soft and top fruit and ornamentals, capabilities for safeguarding ecologically vulnerable species and 
knowledge which points towards more sustainable forms of pest and pathogen control. The development of selective herbicides required an understanding of the mode of action of natural and synthetic growth regulators. These have provided cost-efficient, selective weed control for several decades but concerns over their environmental impacts is now curtailing their use.

\section{Breeding, and nomenclature}

The rediscovery of Mendel's work in 1905 led to the development of science-based plant breeding using parental lines carrying genetically defined characteristics. In the early part of the $20^{\text {th }}$ century East Malling Research Station (now, National Institute of Agricultural BotanyEast Malling Research, NIAB- EMR) led with the definition of rootstocks while the John Innes Research Institute pursued genetic analyses and resultant breeding initiatives. Both lines of research particularly for fruit crops required definitions of morphological and anatomical characteristics which permitted differentiation between cultivars. The potential use of this information for patenting purposes with new cultivars (Anon, 1919) was recognised for ornamentals such as orchids, but was beset with difficulties for fruit not least because of synonomy and antonymy. Hatton (1919) recognised this requirement with black current cultivars. He emphasised the need for accurate nomenclature and taxonomy before experimentation could take place and the importance of correct naming for industrial purposes. This is long-term research as exemplified by Crane \& Lewis (1941) who produced a genetical study of pears. In this they developed a classification key for 81 pear cultivars using leaf margin, leaf midrib, shoot hairiness, shoot colour and leaf colour. They showed where control by dominant and recessive genes existed as for example, the toothed leaf margin " $S$ " is dominant over entire margin " $s$ " (recessive).

Genetic studies and subsequent plant breeding advanced dramatically for horticultural crops, especially fruit, ornamentals and vegetables throughout the history of JHSB. Much of the 
research is, however, recorded in specialist journals. Some reports have, however, appeared in JHSB such as descriptions of the use of haploidisation which is a powerful tool for use by plant breeders in developing $\mathrm{F}_{1}$ hybrids. This technique was exploited for example, in developing new citrus cultivars which fruit more uniformly and with greater reliability in quality. Anther cultures were used seeking haploid clones from clementine and mandarin citrus (Germana et al 1994).

Understanding the mechanisms of gene structure, the transfer of controlling information and its flow from chromosomes into ribosomal instructions which deliver increased plant productivity brought a revolution in clarity and speed with which plant breeders can develop new cultivars. Understanding the activities of specific genes is an outcome of sequencing. For example, the roles of genes $C m F L, C m A F L 1$ and $C m S O C 1$ in the transition from vegetative to reproductive growth in Chrysanthemum morifolium were identified by Li et al (2002). The upregulation of these floral identity and integrator genes correlated with the transition from vegetative to floral reproductive growth in the early development of inflorescences. Later, Wang et al (2010) identified quantitative trait loci (QTLs) for photosynthetic pigment concentration in a double -haploid population of pak choi (Brassica rapa spp. chinensis var. communis). Knowledge of the distribution of QTLs associated with photosynthetic pigment concentration formed a precursor for breeding improved cultivars exhibiting increased resource-use efficiency resulting in speedier growth. The authors noted that gene expression is also influenced by the environment and this affects the usefulness of cultivars bred with raised photosynthetic activity. Marker assisted breeding has become a major tool for plant breeders such as Singh et al (2017) who described the development of Inter Simple Sequence Repeats (ISSR)- and Random Amplification of Polymorphic DNA (RAPD)-derived Sequence Characterised Amplified Region (SCAR) markers for identification of Gladiolus germplasm. Developing markers to distinguish between cultivars helped the breeding of Gladiolus 
worldwide. Defining cultivars individually increases the precision and reliability and these authors for example, identified cv. 'Amethyst' from 62 other cultivars. Nonetheless, traditional techniques are still valuable as typified by Yu et al (2013) who increased yield and quality of essential oils produced by mint (Mentha spp.) by chromosome doubling with colchicine. Tetraploid plants had fewer but larger stomata with increased plant size, internode length, leaf length, leaf width and stem width.

Rational plant breeding and genetics entered horticultural science only a decade before JHSB was founded. New more resource-efficient and pest and pathogen resistant cultivars in all sectors of fruit, vegetable and ornamental production have resulted. Their importance for commerce cannot be over-estimated. Developing new cultivars relies on consistent and welldefined taxonomy and nomenclature as emphasised in several research reports in JHSB and the continued maintenance of collections.

\section{Nutrition}

In the late $19^{\text {th }}$ and early $20^{\text {th }}$ centuries synthetic fertiliser manufacturing industries developed based initially on capabilities for converting gaseous atmospheric nitrogen into solid compounds. Gradually fertilisers with defined nutritional formulations became available from which research could identify the importance and roles of individual macro- and micronutrients. This eventually resulted in the prediction of nutrient needs and development of nutritional strategies. The earliest researchers reported on the effects of particular nutrients, such as the studies of Wallace (1930) who experimented with the nutrition of fruit trees highlighting the effects of deficiencies of phosphorus, potassium, calcium and magnesium respectively, in the shoot and trunk regions of apple trees. Working with cv. 'Stirling Castle' he identified that each element had a significant effect on shoot and foliage growth and the dry matter content of tissues. Large decreases in potassium and magnesium oxides in plant tissues 
resulted from reduced application but decreases in applications of calcium oxide had less marked effects. Wallace (1930) also concluded that in such experiments the bark and wood tissues should be studied separately.

Lime induced chlorosis was, and is still, a major problem for fruit growers. Wallace (1935) investigated chlorosis of fruit trees showing that control might be achieved by injection of iron salts. Injection of powdered citrate of iron (ferric citrate) into holes drilled in tree trunks was a successful remedy.

The long-term nature of field fertiliser experiments for apples was discussed by Wallace \& Spinks (1941). Their work started at Long Ashton in 1920 with cvs. 'Edward VII' (culinary) and 'Allington' (desert) apples. Fertilisers affected most cropping traits irrespective of their organic or inorganic in origins. Deficiencies reduced vigour, foliage quality, blossoming and cropping. Interactions between crop nutritional requirements and genotype were demonstrated by Hoblyn (1941) who showed that the nutritional requirements of apple trees varied depending on the cultivar, rootstock and site. Site effects were evident at East Malling Research Station (NIAB-EMR), Kent, where phosphate had little effect on trees growth and could be omitted. But regular applications of potassium were required especially for cvs. 'Cox’s Orange Pippin' and 'Beauty of Bath'. Nitrogen requirements varied with cultivar, rootstock, site and season, there was a general conclusion that a balance between nitrogen and potassium is crucial. Excessive potassium applications could be associated with the development of magnesium deficiencies resulting in interveinal scorching. Trees on Malling stocks M I, IV and VII were particularly prone to scorching whereas those grafted onto M IX, II, V and XII were not.

Reproducibility and verification of field experiments studying crop nutrition presented major technical problems in ensuring that the results were scientifically repeatable and robust. Nowhere was this more critical than with bulbous ornamentals which also have characteristics 
influenced by the environments in which they are grown over several seasons. Stoughton's (1941) studies of the nutrition of Dutch iris (Iris x hollandica) was one of the earliest where experiments used statistically repeatable factorial designs and computations which analysed for variance. This demonstrated that nitrogen played a dominant role in growth of aerial organs and phosphorus in the development of the bulb. In more detail using laboratory-based experiments Wallace \& Hewett (1946) showed that iron deficiency in trees was of four types: simple shortage, lime induced, association with deficiencies of other minerals, and excess and toxicities of other elements.

Major developments in the study of crop nutrition for ornamental plants resulted from the work of Bunt (1966). Firstly, he examined the utility of John Innes Composts where the mineralisation of organic nitrogen resulted in wide fluctuations in $\mathrm{pH}$. Further, biological activity which determines the rates of ammonia and nitrate production is influenced by temperature, moisture, soil reaction and re-inoculation following steam sterilisation. Bunt developed soilless composts formed of peat and sand which became the basis on which potted plant industries and the entire garden centre trade have developed since the 1960s. Attention also focused on understanding the nutritional requirements of specialist protected crops such as mushrooms. Growers were asking for research-based guidance on the physical and chemical attributes of composts when new crops were "seeded" (sown with mycelium). Salt accumulation takes place in the absence of mushroom mycelium. Flegg (1961) demonstrated that salt accumulation did not affect mycelial fruiting, yield or the average weight per mushroom.

The plant breeding industry asked for guidance on the nutritional requirements of seed crops. In their studies of the nutrition of seed crops of garden beet Beresford \& Jackson (1961) showed significant effects of adding nitrogen, phosphate and potassium improving yield, germination, 
cluster size, weight and colour. This study also provided more basic information describing the effects of environment on mother plant productivity.

Major research was required for the expanding field vegetable industry determining costeffective and economical use of fertilisers. This was particularly important for brassica crops where for example, research demonstrated that base and top dressings with nitrogen were equally effective at increasing yield provided more than 50 percent was applied as a base dressing. Addition of nitrogen has effects on quality, size, proportion of waste, solidarity, smoothness, maturity and the extent of internal browning in Brussels sprout crops. But at higher-rates there was a tendency for plant lodging and early stage development was accelerated by nitrogen applications (Cleaver et al 1971).

New Zealand gradually became one of the world's major apple exporters. The effects of crop load on fruit quality and mineral content were studied by Volz et al (1993) on apple trees cv. 'Cox's Orange Pippin'. Research compared fruit from heavily cropping trees with those from trees with naturally small crops or those where flowers were artificially thinned. In light cropping and thinned treatments, flower bud density was less, and fruit set greater than in heavy fruiting treatments. Fruit from both light cropping and thinned treatments had similar calcium contents, and higher incidences of bitter pit and internal breakdown after storage. The negative effects of light cropping on fruit disorders is probably associated with the low calcium and high potassium contents in fruit. The problems associated with abiotic disorders were discussed by Fernandez et al (2009) in their review of foliar iron-fertilisation of fruit trees. They concluded that deficiency is a common physiological disorder of fruit trees and spraying with iron salts was an unreliable treatment.

Studies over several decades formulated systematic yield response models and nutrient recommendation systems (Goodlass et al 1997) principally for brassicas. Most effective yielding and effects of crops leaving the least residual amounts of nitrogen were calculated by 
computer models using local weather data, measurements of soil mineral nitrogen and simulated crop growth. This approach maximised yields and minimised the risk of nitrogen leaching compared with a "look-up" tabular method. The requirements of other field vegetables were analysed and recommendations produced. Hole et al (2002) reported on skin colour and quality of onion cultivars grown with different nitrogen and irrigation treatments. Improved quality was best achieved by increasing skin numbers and their specific weight using recommended fertiliser strategies.

Far greater precision in the use of fertilisers for all crops has developed over the century as reviewed by Thompson et al (2018) who considered the nitrogen management strategies prevalent across Europe such as Nmin, KNS and N-expert and identified the importance of the UK's recently revised Nutrient Management Guide (RB209) (Anon, 2017). Sap analysis was advocated as a useful new tool for nitrogen management.

Increasingly, there is recognition of the need for considerations of soil biological activity when formulation fertiliser strategies. This is emphasised, for example, in the report of Fernandez et al (2014) describing the responses of young tomato seedlings to drip-irrigation containing the arbuscular mycorrhizal fungus Glomus iranicum var. tenihypharum sp. nova. Adding this microbe increased nutrient uptake into leaves and intrinsic water use-efficiency and tomato fruit yields.

Identifying, manipulation and controlling the nutrient requirements of crops are major factors in increasing crop productivity in logical and coherent husbandries. All horticultural crops have benefitted from initial research which identified their needs for specific nutrient regimes regulated by soil and aerial environments, seasons and sites. Long and detailed research has been and continues to be required since changes in crop production strategies predicate alterations in nutrient demands. Recent developments in technological capabilities for 
producing mathematical models of nutrient assimilation based on considerable accumulated research-based knowledge are increasing the precision with which fertiliser strategies may be devised and applied.

\section{Crop protection}

Pests and pathogens

Early editions of the JHSB provided opportunities for publishing the identity and nomenclature of important crop pests and pathogens. Most of these organisms were known in vernacular and empirical terms for centuries but often without a rational basis which connected the damage with the causal organism. In some instances, rationalising identity was especially important since organisms had several stages in their life cycles which had been given divergent descriptions and names. Research studies began forming a scientific basis for understanding the biology, host-parasite interactions and control of these organisms. For example, the woolly aphid of apple and elm (Eriosoma lanigera) originated in 1796 on apple material imported from North America and known in Great Britain as American Blight or American Bug; Theobald (1920) identified life cycles where elm is the principle host and biological strains which live wholly on apple. Subsequently, Theobald (1921) identified treatments for use by apple growers and the presence of immunity in some rootstocks. These showed that the rootstock cv. 'Northern Spy' was almost always unaffected whereas 'Paradise' stocks were inevitably infected. Studies published during this period focussed largely on problems afflicting top and soft fruit crops. An example of the latter is the work of Massee (1930) with the mite of strawberry (Tarsonemus fragariae) which had become widespread in crops particularly of cv. 'Royal Sovereign' causing crinkling and desiccation of leaves making them brittle. Young developing leaves turned silvery brown and runners were malformed and producing unhealthy plants. Massee (1930) recommended spraying with materials such as 
white oil emulsion and sulphur. In subsequent decades chemical controls became more accurate and efficient with numerous papers describing large numbers of synthetic agrochemicals. Many of these materials were later withdrawn on environmental and public health grounds. The JHSB has brought studies up to date by publishing detailed review articles such as Gordon et al (1997). They reviewed Rubus pests in Europe identifying that many pests are crop specialists, the effects of changing crop husbandry especially the increase in protected cropping which is altering the spectrum of pests and the form of damage caused. Changing attitudes towards the use of synthetic chemicals encouraged moves towards integrated pest management. This includes using forms of resistance, naturally occurring pesticides and biological control. The Arthropod pests included by Gordon et al (1997) affect raspberry (Rubus idaeus), cultivated blackberry (R. laciniatus, $R$. procerus) and Rubus hybrids, e.g. Tayberry and Loganberry. New pest species or biotypes were discovered on Rubus, resulting from changes host cultivars, climate change induced pest movements and alterations in husbandry and control strategies. For example, most soft fruit production now takes place under polythene covers. As a result, Emden and Hadley (2011) described how cypermethrin, a synthetic pyrethroid insecticide, is degraded by ultra violet (UV) light reducing effective life to 3 weeks. The use of UV opaque plastics prevented this degradation, consequently, the usefulness of this insecticide was extended to periods as long as 26 weeks and in some instances even longer. This research has implications for the use of cypermethrin and similar molecules under plastic sheets when controlling insect pests for example in strawberry crops.

Reporting of scientific research into the causes of fruit diseases was, as with pests, an initial pre-occupation of authors in JHSB. This built connections between symptoms, damage and causal organisms. Clarifying the nomenclature and taxonomy of pathogens was at least as important as for pests. Apple scab (Venturia inaequalis) and powdery mildew (Podosphaera leucotricha) were, and still are, major causes of crop loss. Their early incidence and control in 
apple was described by Moore (1930). He estimated apple scab severity by the "category method", identifying the epidemiology of conidia dispersing from pustules on young wood over a period of weeks. The control of apple powdery mildew was achieved with similar control methods and in particular for the noticeably susceptible cv. 'Cox's Orange Pippin'. Marsh and Walker (1932) building on the original identification and studies of apple scab by Salmond $(1906,1908)$ who described three forms of invasion and epidemiology of the fungus studying cv. 'Lord Suffield'.

Pathogens of soft fruit crops were also identified in this period and the diseases caused described as for example Hickman's (1941) report of the red core disease of strawberry caused by Phytophthora fragariae. This research was stimulated by outbreaks in Kentish plantations of a disease already well known in Scotland (the Lanarkshire disease) and also found in Hampshire, Somerset, Devon and Cornwall. Hickman (1941) described the epidemiology and symptoms of the disease, morphological and physiological characters of the fungus and the naming of $P$. fragariae. At this time research attention also started focussing on the pathogens of vegetable and salad crops such as Brown's (1936) work on the Botrytis cinerea induced disease of lettuce (grey mould) and its control. The production of lettuce seedlings in cold frames prior to transplanting risked damage from diseases, especially grey mould. The research identified interactions with environment particularly high-risk periods in December and January when light levels are low and the cold frame atmosphere is humid.

Disease control methods mirrored those of pests with large numbers of agrochemicals being produced and marketed from about the 1970s to 1990s. Thereafter, many disappeared as they were considered as environmental risks. Research interest shifted towards tracking the upsurge of alien pathogens coming from other Continents. Harris (1991) reviewed in great detail the range of Phytophthora species which cause disease in fruit crops particularly apples. These pathogens are now spreading worldwide and can cause very substantial damage or death. Host 
resistance and cultural controls are major means of limiting pathogen induced damage linked with using disease-free certified stock. Recognition of the impact of environment on hostpathogen interactions also re-emerged. Soil type, soil texture and structure tree age, height of the graft union and interactions between stock and scion all influence the extent and severity of disease caused by these organisms.

Some early research reports while reflecting husbandry and crop protection of their period advanced ideas which now would be considered very topical. Examples of this, are the recognition of the importance of environment on predisposition to disease damage by Selman (1947a). He reviewed the previous literature and emphasis placed by experienced growers on the association between the disease and various environmental factors. Thus, lack of fertilizer, cold nights, frosty fogs, treatment at planting, planting in newly turned ground, excessive dryness of the hotbeds and the use of pigeon manure had all variously been held responsible for encouraging disease development. Very similar views have been held by potato growers (and by some scientific investigators) as to the cause of heritable Leaf-Roll ("Curl ") in the potato. A summary of some of these early views has been given by Orton (1914) and later by Pethybridge (1940). Selman (1947b) also reported on the association of virus diseases with certain soil types, some of which may have been related to soil water conditions. Experiments with young plants (Selman, 1946) had concluded that soil conditions, as determined by the inclusion of various amounts of fertilizers, may affect the susceptibility of the tomato to infection with Tobacco Mosaic Virus (TMV).

Virus control particularly in vegetatively propagated crops such as top and soft fruit required the production and maintenance of virus-free plants typified by raspberry (Chambers 1961). There were differences in the manner by which individual cultivars responded to treatments. Virus removal was more effective with cvs. 'Norfolk Giant' and 'Malling Jewel' compared 
with cvs. 'Lloyd George' and 'Malling Promise'. Results suggested that viruses vary in abilities for multiplication in plants held at $32^{\circ} \mathrm{C}$ for 6 to 10 days.

Field studies demonstrated that bulb yield of virus-free stocks of Narcissus cv Carlton was 9 percent higher than comparable untreated bulbs and produced heavier bulbs at lifting (Sutton et al 1988). Virus-free stocks flowered 3 days earlier than untreated bulbs but there was no effect on flower number or quality. Alternatively, some virus infections can have beneficial effects (Semancik 1997) as with application of selected viroids for dwarfing and enhancement in the production of cv. 'Valencia' oranges. Infection specifically with the viroid CVd-IIa reduced canopy volume accompanied by a yield increase per tree whereas, other viroids caused yield reductions.

Molecular biology makes possible the development of pathogen resistant cultivars and is now one of the centres of interest for plant breeders. Chungwongse et al (2002) identify the molecular mapping of the Ph-3 gene for late blight (Phytophthora infestans) resistance in tomato. This is a major disease of tomato and potato crops worldwide. Single gene resistance has been identified in Lycopersicum pimpinellifolium as related to gene $P h-3$ and this can be combined with $P h-2$ from $L$ hirsutum in attempts at gene pyramiding which reduces the rate at which resistance is eroded by the evolution of tolerant strains of the pathogen. Earlier Watt et al (1999) published a well-balanced review of the opportunities and disadvantages of transgenic molecular technology. Regrettably, the foresight contained in this article has been brought to nothing in Europe while in the rest of the world it has been more acceptable.

Molecular biology has brought much improved means for identifying and classifying disease causing organisms as with the faster inoculation assay for the fungal pathogen, Armillaria spp. using herbaceous plants (Ford et al., 2017). Herbaceous hosts expressed symptoms more quickly compared with woody ones increasing the rapidity of diagnosis. Similar techniques may also be used for the identification of resistant genotypes for breeding programmes as 
developed by Nabeshima, et al (2014) who evaluated chrysanthemum stunt viroid (CSVd) infection in newly expanded leaves from CSVd-inoculated shoot apical meristems as a method of screening for resistant chrysanthemum cultivars. In vitro screening provided an effective means for identifying resistant genotypes which could be used in breeding programmes.

Biological control

Understanding that pests and pathogens are part of biologically balanced ecosystems and consequently have predators which control their populations was reported in early editions of JHSB. Findings by Miles (1921) describe the role of crab apple and old cider trees in harbouring certain insect pests and their predators. He listed extensive numbers of species present in orchard trees planted from the 1820s onwards in the neighbourhood of Long Ashton, Somerset. The presence of Adalia sp which feeds on aphids and Brachytarsus varius which lays eggs in Coccus spp. (scale insects) were particularly noted. Later, Miles (1922) recorded the control of apple blossom weevil (Anthomorus pomorum) by ichneumon parasites which are efficient enemies of this pest. This theme was picked up by Corke (1974) with Perry pear trees showing severe symptoms of silver leaf disease (Stereum purpureum) were reduced when trees were treated by implantation with inoculum of Trichoderma viride an antagonist of the pathogen.

Commercialisation of biological control is widespread in protected crops as noted by Khalil et al (2009). These researchers identified the effects of growing medium on the interaction between biocontrol agents and tomato root pathogens in closed hydroponic systems. Biocontrol could be achieved using several commercial materials but their efficacy varied with the pathogen and host combination. This typified the situation with bio-control such that it is specific both in terms of the host-pathogen combination and the environment in which it is applied. Nonetheless, Olle and Williams (2013) described how 'effective microbes' in the soil influence plant growth, encourage the conservation of energy, solubilise soil minerals 
suppressing plant pathogens and diseases and improve the efficiency of photosynthesis and biological nitrogen fixation. This has positive effects for vegetable production, product quality and yields.

\section{Abiotic disorders}

Research reporting disorders resulting from adverse environmental conditions have been a persistent theme in JHSB. The influence of shade and within-tree position affecting apple fruit size, colour and storage quality was described by Jackson and Sharples (1971). Fruit from the outer parts of trees were larger and better coloured but more susceptible to bitter pit, rotting due to Gloeosporium and soft rot fungi. Bitter pit was related to decreases in the calcium and potassium ratio in the fruit. Initially advice suggested the labour-intensive practice of picking and storing fruits from different parts of the tree separately. Summer pruning modified the leaf and fruit ratio improving the storage quality of larger fruit (Boon 1980). Spraying with calcium nitrate reduced bitter pit and tissue breakdown diminishing the need for pruning. Explanations of complexities in the mode of interaction between calcium and tissue breakdown required detailed research as typified by the work of Adams and Ho (1992) studying susceptibility of modern tomato cultivars to blossom-end rot. Blossom end rot could be attributed to a lack of co-ordination between cell enlargement in the distal placental tissue and the transport of calcium via the xylem and intercellular movement towards susceptible tissues in the distal parts of the fruit locules and placenta. In turn, this could be related to variations in uptake of calcium by roots which varied between the cultivars studied hence, some were more blossom-end rot susceptible than others.

Similar conclusions were reached for field vegetables and salads as described by Hilton et al (2009) in studies of influence of agronomic factors on the visual quality of field-grown, minimally-processed lettuce. The incidence of pinking and browning in iceberg lettuce could 
be related to calcium application under conditions of low potassium and nitrogen ratios. Variations between genotypes are also important as demonstrated by Toivonen (1992) who found that post-harvest enzymic browning of parsnip resulted from susceptibility in root surface cells to injury. Some cultivars being more susceptible than others.

Interactions between environment and genotype resulting in abiotic disorders is equally applicable for ornamental crops as demonstrated by Cameron and Dixon (1997). They showed that air temperature, humidity and rooting volume affects the degree of freezing injury in Rhododendron species and hybrids and other perennials. Treatment with minimal temperatures prior to freezing acclimatised the tissues of Rhododendron leaves to otherwise damaging freezing conditions. But below this threshold prior acclimation provided little protection. OrenShamir and Levi-Nissim (1997) identified temperature effects on the leaf pigmentation of Cotinus coggygria cv. 'Royal Purple'. Low temperatures encouraged the increase in anthocyanin concentrations in young and mature leaves accompanied by an inhibition of growth. These responses are now ascribed to similar cellular processes as defined by TorreGonzales et al (2018) in their analysis of metabolic and nutritional biomarkers in Brassica oleracea cv. 'Bronco' under alkaline stress. Alkaline conditions due to growing in calcareous soils causes stress in Spanish brassicas. This results in reduced growth, biomass, and capacities for coping with oxygen stress because of loss of superoxide dismutase (SOD). Visually mineral nutrient deficiency symptoms or the accumulation of the amino acid proline, can also be used as biomarkers for cellular stress responses.

Pest, pathogen and abiotic disorders are major causes of losses in yield and often more importantly crop quality. Identifying the organisms and environmental conditions responsible for these losses and developing means for their control significantly increased the reliability, precision and profitability of horticultural crops. Research reported in JHSB reveals the logical development of identification and understandings of the means of control. In some instances, 
the ideas underpinning research were considerably in advance of what was for their time mainstream thinking. Some results now being reported in JHSB point towards recognition of the essential requirement for solving the paradox between effective control and environmental equity. Developing sustainable pest and pathogen controls causing minimal environmental damage is key to future production of fruit, vegetables and ornamentals.

\section{Crop cultivation and management}

An early paper taking JHSB beyond fruit crops was that of Turner (1924) who reported results from trials with autumn-sown spring cabbage at the then Cannington Farm Institute in north Somerset (now part of Bridgwater and Taunton College). North Somerset enjoys a climate which favours early spring vegetable production. Results emphasised the importance of good seed, identified cultivars suitable for the area, sowing times and requirements for transplanting before the onset of unfavourable winter weather. As an essential requirement Turner (1924) emphasised soil health which permits "steady growth" in the autumn which can accelerate in the following spring producing early hearting of crops. These observations resonate with present-day strategies for conservation and management which recognises biological sustainability as key for soil health.

Late spring, summer and autumn maturing vegetable crops were drilled directly into land and the resultant plants manually thinned which was a laborious task. Husbandry efficiency increased with the development of precision drills which placed single seeds at specified distances. Exploiting this technology effectively required research information describing the field establishment of crop seedlings and the influence of sowing depth on subsequent plant emergence (Heydecker, 1966). His research showed that in crops such as cabbage, carrot, lettuce and onion sowing date and seeding depth significantly influenced resultant percentage emergence. Optimal sowing depths were established for seed of each crop type identifying that 
accurate means of depth adjustment is a priority for mechanical seed drills. This research required a statistically valid platform, this emerged from studies such as Nelder \& Moss (1956) studying spacing of lettuce grown in heated glasshouses. They showed how yields rose significantly, in statistical terms, as spacing decreased and that year-to-year variation had lesser impact where plants were closer. There was no significant difference in yields using either triangular or square planting layouts. Market value was however, increased at tighter spacings because more lettuces were harvested. Spacing also affected the earliness in globe beet and carrot crops (Warne 1961). Spacing distances of $2.5 \mathrm{~cm}$ for carrots and $5 \mathrm{~cm}$ for globe beet resulted in the most productive yields.

Opportunities for accelerating germination and crop establishment using previously germinated seed ahead of drilling developed as new preparation and incubation technologies became available. These methods resulted in earlier emergence compared with standard dry graded and ungraded lettuce seed (Gray 1978) and more uniform maturity reducing the number of harvests required. Further research examined the use of previously germinated carrot seed with and without irrigation. Germination and seedling development were advanced by up to 10 days compared with natural seed (Finch-Savage 1984). Early crop growth and maturity was accelerated by using previously germinating seed, but differences largely disappeared at harvest when root size, yield, uniformity and quality were similar.

Lack of uniformity means particularly with brassica crops several sequential harvests are required adding costs and reducing quality. This is exemplified by Chung's (1982) study of the effects of plant density on the maturity and once-over harvest yields of broccoli (Brassica oleracea var. italica). The most cost-efficient harvests were obtained between days 89 and 92 after transplanting when the highest proportion of machine harvested spears were of the required size grade for processing with minimal waste. 
Determination of seed viability, deterioration and subsequent quality improvements resulted in improved vigour in developing seedlings and juvenile plants. Selvi \& Saraswathy (2018) reviewed the literature relating to stored onion seed in India. Defective storage results in low yields and poor quality.

Identifying genotype and environmental factors controlling seed quality, germination and growth with subsequent implications for crop vigour played especially important roles in increasing the reliability of field vegetable and salad crops. Improved prediction of crop maturity was and is, an important element in increasing the precision of brassica and salad crops husbandry.

Identifying appropriate sowing and planting geometries, maximised the returns from increasingly expensive hybrid seed and sharpened the precision of cropping. These apparently simple parameters form the basis for detailed understanding of the performance of individual plants within large field populations. Technical developments such as drills offering precision placement and opportunities for the use of pre-germinated seed indicate the manner by which horticultural science makes advances by information and knowledge flowing from the field to the researcher and vice versa. These multi-directional matrices were especially important for studies of the effects of seedling and transplant vigour on subsequent crop uniformity and productivity.

\section{Interactions between environment and crop growth}

The impact of environment on productivity is a continuing theme throughout the studies published in JHSB for all crop sectors. Some early studies focused on the environment as influenced by husbandry operations such as pruning of top fruit. Knight (1930) reported on the effects of pruning "leaders" and of the absence of "laterals" on the rate of stem growth in apple and plum. The absence, in apple, of lateral shoots on older stems had practically no influence 
on the rates of extension growth or of diameter of newly developing shoots. Experiments with plum trees gave similar results. It was noted that a downward wave of cambial activity from newly developing shoots resulted in the increasing girth of older stems.

Early environmentally controlled research used successional sowing and planting of seedlings in glasshouses throughout the seasons as a means for gaining sequential information. Technology for building light-controlled growth cabinets arrived in the early 1960s. These facilitated far more detailed research.

Studies of flowering in glasshouse tomato plants related light duration and plant age (Cooper 1961). The age at which flower buds first appeared was correlated with day-length. Tomato is a long day (LD) plant so naturally lengthening days resulted in younger plants flowering more quickly. Quantifying relationships between leaf area at flower bud appearance and day-length identified the critical day length at 12 hours. Later studies also showed that shading by leaves also affected the cropping capabilities of glasshouse tomatoes (Cockshull et al 1992) giving guidance on more effective crop defoliation.

Apical dominance and flower initiation are important characteristics for horticultural crops not least ornamentals, such as roses. Flowering in rose side-shoots is inhibited while apical dominance from a terminal bud remains (Cockshull and Horridge 1977). The universality of this finding was demonstrated by similar results being obtained from crops as divergent as mango and chrysanthemum. Factors such as proximity to the roots and maturity may also influence of leaf number, Cockshull and Horridge (1977) suggested. Extensive studies of the effects of light quality on the growth and development of plants was described by Vince et al (1966) as facilities controlling light composition, day-length duration and temperature became available. 
Even then studies in the field and glasshouse continued providing valuable applied research knowledge. Variation in the growth habit of red raspberries was correlated with cane height and node production (Jennings \& Dale1982). Node number is a principal yield component and that is improved by selection for moderately vigorous genotypes which eases management of plantations. Excessive vigour leading to massive cane growth makes fruit picking difficult and is wasteful of cropping resources.

Similar studies reported on relationships between leaf number and fruit development in mango (Mangifera indica) et al 1982). Correlations between leaf to fruit development showed that there is a resource requirement for more than 30 leaves per fruit. When this amount of foliage cover is not achieved carbohydrate source and sink relationships result in resources being withdrawn in support of fruiting from branch tissues. That effect helped explain the biennial bearing characteristics of some mango cultivars. Non-biennial bearing cultivars have higher ribulose-1,5-biphosphate carboxylase oxygenase (RuBisCO) activity increasing the potential for producing adequate carbohydrates in support of fruit development in the bearing year.

Humidity in day- and night-times affected yield and quality of glasshouse cucumbers (Bakker et al 1987). Interactions between humidity and the production of high-quality cucumber fruit was most successfully exploited with high day-time humidity. Entire $24 \mathrm{hr}$ cycle high humidity could be damaging as that encouraged calcium deficiency in leaves. For protected crops more generally, Grange \& Hand (1987) reviewed of the effects of atmospheric humidity on the growth of horticultural crops. They showed that there is little effect on horticultural crops of humidity levels between 55 to $90 \%$ RH. Lower RHs cause water stress reducing growth and development in for example polluted atmospheres. Higher RHs contribute to crop damage but there may be conditions when higher RHs are desirable for short periods to avoid calcium deficiency by generating root pressure, in fruit or young foliage where bio-controlling fungi are used to control pests and in the propagation of leafy cuttings or in tissue culture. 
Environment in field crops particularly those occupying land over prolonged periods significantly affects productivity of both ware and seed plants (Brewster 1982). Overwintered cultivars of bulb onions respond to differing propagation environments especially temperature and daylength. Production of early-maturing bulb onions from late summer sowings became an established commercial practice in the Great Britain in the 1980s and 1990s. Breeding cultivars suitable for this form of husbandry required an understanding of inflorescence structure and seed development in Allium. For seed production it was apparent that onion flowering is related to temperature queues interacting with growth stage.

Further studies of environmental queues resulted in the development and evaluation of techniques for predicting harvesting maturity and uniformity in crops such as iceberg lettuce (Wurr et al 1992). Two seasons of field studies concluded that heart formation and leaf expansion resulted from the interaction of environment with cultivar growth stages. Consequently, prediction using day-degree information provided means for more accurately estimating harvesting dates. Environmental interactions may lead to undesirable characters developing such as bolting in leeks (Wurr et al 1999). Crops of early season leek cv. 'Prelina' were grown in four experiments at Wellesbourne, Warwickshire and in Cornwall from 1995 to 1997. Treatments applied included time of sowing, plant raising temperature, transplant type and covering regime. Results demonstrated that environments during early growth stages influences the onset of flowering. As a result, growers were advised that delaying transplanting would reduce the number of bolters. Models which predicted rates of increase in leek diameter and the onset of flower stalk extension were produced.

Requirements for understanding the interaction of environment and crop location increased in importance as the implications of climate change were appreciated (Kenny \& Shao 1992). An assessment using latitude and temperature indices predicted climate suitability for grapes in Europe. This showed that a $-3{ }^{\circ} \mathrm{C}$ threshold for winter temperature was needed and that 
excluded areas where winter damage would be too severe for vine survival. A $1{ }^{\circ} \mathrm{C}$ rise in temperature due to global climate change would significantly increase the areas where grapes could be profitably grown.

Environmentally induced variations interacting with husbandry practices are found in all aspects of crop production. For example, bulb crops such as Narcissus show yearly variations in flower and bulb yields, dates of shoot emergence, bloom and foliage senescence and responses to cold storage (Hanks 1996). These are in part the result of yearly variations in weather but also arise from differences in planting depth and bulb orientation resulting in loss of uniformity.

Finding causes of erratic behaviour permits mathematical modelling which results in more precise crop location and subsequent husbandry. Studies of growth, development and yield of onion (Allium cepa.) as affected by temperature and carbon dioxide concentrations in the atmosphere (Daymond et al 1997) indicated how changing climates could influence crop production. Changing the environment by raising carbon dioxide levels increased bulb yields by 29-37 percent but 35-51 percent of yield still resulted from the influence of genotypic factors. Higher carbon dioxide levels resulted in increased bulb growth, earlier initiation of bulbing and greater radiation-use efficiency.

Climate change infers altered temperature regimes. Reeves et al (2001) developed a temperature-based model which predicted curd initiation in two winter cauliflower genotypes known as 'March' and 'December / January'. An upper limit of $17{ }^{\circ} \mathrm{C}$ was an accurate maximum for both groups with lower limits of 4 and $9{ }^{\circ} \mathrm{C}$ respectively, correlated with field data. Temperature also affects the growth of raspberry and its genetic interactions were discussed by Gotme et al (2014). Short-term exposure to high-temperature affected total gene expression in the leaves of four raspberry (Rubus idaeus) cultivars. Most Rubus originate from 
cool temperate areas consequently elevated temperatures altered gene expression; some were up-regulated while in others activity was reduced. Temperature effects were also found by Famiani et al (2009) with the soluble sugar and organic acid contents and the occurrence and potential role of phosphoenolpyruvate carboxykinase (PEPCK) in gooseberry (Ribes grossularia), another temperate soft fruit. Increases in malic and citric acids in gooseberry fruit (cv. 'White Smith') up to 80-90 days after blossoming are followed by decreases and concomitantly raised sucrose levels at full ripening (110 days after flowering). This explained the cycle of suitability for culinary and dessert purposes for this crop. High temperatures in grapevine (Vitis vinifera) leaves during the seedling stage limited photosynthetic efficiency and consequent growth of grapevine seedlings with an upper limit of $38^{\circ} \mathrm{C}$ (Xiao et al 2017). These results mirror those of Sonsteby \& Heide (2017) who demonstrated that flowering performance and yield of established and recently planted strawberry cultivars (Fragaria $\mathrm{x}$ ananassa) are affected by raising temperature and photoperiod. Most strawberry cultivars initiate flowering with short days (SD) and intermediate temperature followed by LD except for some everbearing cultivars. Consequently, autumn planting was advocated particularly for crops in northern temperate areas.

Increased understanding of the interaction between environment and crop growth and reproduction has produced substantial changes in industrial practices. The ornamental industry was revolutionised by fundamental research studies which revealed the effects of photoperiodism for flower crops such as Chrysanthemum, rose, Poinsettia and many others. Entirely new production systems have been established which exploit this knowledge. The growth and fruiting capacities of protected vegetable and salad crops similarly benefitted from understandings of the cyclic effects of temperature, humidity and ventilation. In combination with breeding more productive and market appropriate cultivars sophisticated manipulation of environment has raised yields and quality several fold. 
Field vegetables and soft and top fruit including vine production has gained significantly by the application of knowledge of the impact of temperature, seasonal cycles of daylength on crop initiation, growth and reproduction. The importance of this knowledge in interpreting the effects of climate change, increasing or decreasing temperatures, carbon dioxide concentrations and weather variability further emphasises the key position of horticultural science in providing for human well-being.

\section{Water use-efficiency}

The value of irrigation for increasing yields and quality started being studied seriously in the 1950s. Questions such as how much and how often should irrigation be applied were answered by studies such as those of Salter (1961). He identified the irrigation need of early summer cauliflower in relation to stage of growth, plant spacing and nitrogen level. His research showed that irrigation increased yield especially when applied just prior to harvest. Subsequently, Salter (1976) concluded with onion crops that combinations of cultivar, planting or sowing date, irrigation and storage for a year-round supply of bulb onions from UK sources is feasible.

Similarly, growers of top fruit needed information on irrigation volumes and application timing. Studies of the influence of soil moisture on apple root growth and root and shoot ratios identified that moisture stress, fluctuating moisture availability and waterlogging in the summer months reduced growth and increased root and shoot ratios of cv. 'Granny Smith' apple on MM 115 rootstocks (Cripps, 1971). Reduction in root growth resulted from moisture stress as roots proliferated less in dry soil hence the overall structure of root growth alters. Frequent irrigation (in Australia) maintaining field capacity produced the largest trees. Trees grown on seedling rootstocks had greater tolerance of either moisture stress or waterlogging.

Studies of the relationships of irrigation and shelter from wind on emergence of carrot and cabbage seedlings (Drew 1982) showed that for both crops, irrigation has major impacts on 
emergence. Shelter significantly increased the rate of emergence of irrigated carrots. Shelter increased soil temperature by up to $3{ }^{\circ} \mathrm{C}$ (usually $1-2{ }^{\circ} \mathrm{C}$ ) with maximum effect at $15.00 \mathrm{hr}$. and a minimum of $0.5^{\circ} \mathrm{C}$ at about $06.00 \mathrm{hr}$. The effects of shelter were greatest on sunny days. Soil temperature was also increased by ridging on south facing slopes, or mulching with black plastic.

Public health concerns emerged as to sources of irrigation and their safety (Nichols et al 1971). Contamination of lettuce irrigated with sewage effluent showed that using water abstracted from streams may contain faecal contamination from discharges and was found to infest lettuce crops with Escherichia coli I and other coliform bacteria.

Huguet et al (1992) investigated specific micro-morphometric reactions of fruit trees to water stress and automated irrigation scheduling. Shrinkage of fruit tree stems is a characteristic of water stress and can be measured with linear variable differential transformers. Two patterns of shrinkage were identified: the peach-tree and the apple-tree forms; in the former maximum daily shrinkage increased as water stress increased, in the latter shrinkage was less than its well-watered value. The effects of water deficit on vegetative growth, fruit growth and fruit quality in cv. 'Cox's Orange Pippin' apple showed that water deficits imposed in December (in New Zealand) reduced shoot growth by 37 percent; proportions of cracked fruit increased but little effect on fruit size or titratable acidity (Irving \& Drost, 1987. By imposing water deficit in March during harvest shoot growth was again reduced but fruit size was unaffected. Reviewing the influence of temperature and water supply on apple fruit growth and the development of orchard-grown trees Atkinson et al (1996) discussed genotype x environment interactions, impact of molecular biology and its techniques, tissue culture and micropropagation. Relationships between sap flow, hydraulic conductivity and the anatomical characteristics of stems and roots in apple rootstocks of different vigour indicated that sap flow is less active in dwarfing rootstocks when leaf area is taken into account related to the diameter 
and density of large xylem vessels (Iwanami et al, 2009). The ratio of phloem and xylem decreased as rootstock vigour increased. This is thought to be related to the ability of roots to absorb and transport water as expressed as root specific sap-flow, this could be a useful parameter in breeding new rootstocks of differing vigour.

Research moved further into analysis of the effects of irrigation and crop quality as with the report of Jorquera-Fontena et al (2017). This work identified that in blueberry (Vaccinium corymbosum) fruit water dynamics during growth, using an ecophysiological model, showed that larger fruit mass related to smaller fruits but had little effect on sugar content. Larger fruit mass was caused by water flux rather than pressure differences.

Irrigation plays a major part in improving crop yields and quality. Discovering the amounts required and frequency of application built in practical terms on the knowledge developed regarding soil retention and water uptake. Applying this for crop production and understanding the effects of water movement within plants contributed in raising field and orchard cropping precision. Recognising how water is moved in plants transporting resources from sources into sinks and consequent impacts on aerial and root growth provides a basis for raising productivity. In this horticultural science has utilised the significant engineering developments which have enhanced the efficiency of irrigation equipment. Pairing in research terms"why water is needed" with best practice in "how it is delivered" is a considerable achievement.

\section{Storage}

Storage especially of top fruit was one of the earliest aspects of crop production that received scientific attention. Studies of gas storage of fruit for example, identified optimum temperatures and atmospheres and Kidd \& West (1930) considered the effects of oxygen and carbon dioxide concentrations on sucrose and acid levels in fruit. Carbon dioxide concentrations could be raised as high as 9 percent for apple especially cv. 'Bramley's 
Seedling' they reported. Reducing oxygen concentration and temperatures to $1^{\circ} \mathrm{C}$ were associated with internal breakdown of fruit. Further experiments (Trout, 1930) on the storage of pears in artificial atmospheres confirmed Kidd \& West's (1930) results with apple. Carbon dioxide concentrations below 10 percent and the exclusion of oxygen extended the storage life of pears by 50 percent. These conditions appeared to prevent the appearance of scald in susceptible cultivars and led to normal ripening.

The formation of ethylene during storage and its significance in the ripening of fruits (Gane, 1936) began being appreciated. Initially, it was noted that ripe apples generated a "gaseous substance" which produced epinastic effects on the petioles and leaves of growing plants similar to the known effects of ethylene. The active substance from apples reacted with bromine forming ethylene dibromide via the formation of diphenyl-ethylene-diamine with aniline, this confirmed that the active "gaseous substance" was ethylene.

Storage began being considered for field vegetable crops (Smith, 1941) particularly broccoli and cauliflower. Research showed that storing at $0^{\circ} \mathrm{C}$ was preferable compared with higher temperatures irrespective of air or gas storage. High RHs prevented wilting and gas-mixtures of 10 percent carbon dioxide were preferable compared with 5 or 15 percent, reducing oxygen concentration alone was of little value. The practical recommendation from this work was using atmospheres consisting of 10 percent carbon dioxide, 11 percent oxygen and 79 percent nitrogen.

At this time, potatoes and other root crops were stored in outdoor clamps. Distribution of temperatures in potato clamps and their influence on sprouting and sugar content was reported by Barker \& Wallace (1946). Comparing differing depths of earth covering of clamps showed how this caused altered temperatures compared with ambient conditions as tested at various places in the pile and also affected the sugar content of the tubers. 
Understanding changes in the biochemical constituents of fruit resulted in studies of the amounts of acid in developing and harvested fruit of cvs. 'Bramley's Seedling' and 'Worcester Pearmain' (Kidd et al., 1951). Research showed that post-harvest there is a period when acid levels remained stable, thereafter they declined in both cultivars but more quickly in the dessert cultivar. Rates of loss were related to cytoplasmic structure and the area of the vacuole and their interface resulting from cell size and number. Interest in top fruit storage gradually focussed on relationships with biotic and abiotic stresses (Sharples, 1968). Larger fruits were more susceptible to bitter pit and rotting caused by Gloeosporium perennans but less susceptible to low-temperature injury. Bitter pit was related to the high ratios of potassium to calcium; low temperature injury was related to low dry matter content. Rotting encouraged by low temperature injury was related to fruit maturity as determined by progression to the climatric rise in respiration rates. Later work dealt with top fruit quality in storage particularly cv. 'Cox’s Orange Pippin' apples especially, studying fruit mineral composition during development (Johnson et al.,1987). One goal was bitter pit prediction and control this could be achieved by analysing calcium and potassium and calcium ratios in August and at harvest. Fruit firmness was related with percentage dry mater from mid-July to harvest. Fruit colouration following storage became important as consumers increasingly demanded colourful fruit (Curry 1997). That resulted in studies of the interaction of temperatures and anthocyanin accumulation in apple tissue. It appeared that pre-climacteric fruit formed more anthocyanin that post-climacteric fruit and this effect varied with different cultivars and temperatures.

Identifying and controlling biotic and abiotic stresses is crucially important for the healthy storage of field vegetables. Deterioration of stored beetroot resulted from physiological and not pathogenic causes such as Fusarium species and bacteria Tucker (1981) determined. Also rising in importance was the storage of glasshouse grown fruit. The feasibility of using alternating temperatures of 2 and $20^{\circ} \mathrm{C}$ thereby delaying the ripening of mature tomatoes 
without adversely affecting appearance or taste of the ripe fruit was investigated (Hobson, 1981).

Development of improved storage technologies resulted in the availability of ice-bank stores. In studies of root crops such as swedes cv. 'Laurentian Purple Top' stored with or without postharvest dipping in fungicides, in an ice-bank cooled store Geeson et al., (1989) advocated storage at $0^{\circ} \mathrm{C}$ and $97-98$ percent $\mathrm{RH}$. The practical applications of long-term ice-bank storage of swedes for processing and for the fresh market became evident.

Controlling fungal induced deterioration in stored fruit is a vital prerequisite for successful marketing. But demands for pesticide-free fruit meant of controlling post-harvest rots by methods other than using agrochemicals. Diversified control methods were tested for citrus fruit (Porat et al., 2002). Combinations of hot water, sodium bicarbonate and biocontrol were studied. Using 2 or 3 of these treatments substantially reduced post-harvest rots in cvs. 'Sharmouti' orange and 'Star Ruby' grapefruit and were almost as effective as using synthetic chemicals. Additionally, ethylene suppressants began being used (Pristijono et al., 2017). Postharvest UV-C (ultra-violet section C) treatment combined with 1-methycyclopropene (1-MCP) followed by storage in continuous low-level ethylene atmosphere, improved the quality of stored tomatoes. These treatments significantly increased the storage period of green tomatoes in the supply chain without the need for refrigeration; at the point of sale fruit was firmer and had higher total phenolic contents. Further investigations (Li et al., 2017) showed the interaction of ethylene concentration and storage temperature on post-harvest life of the green vegetables pak choi, broccoli, mint and green bean. Storage at low ethylene concentrations allowed a 14-day period in the supply chain for these vegetables reaching the market in a good quality state and acceptable for the consumer avoiding low temperature storage. 
Reducing ethylene levels around produce delays the senescence of fruit and vegetables and therefore, has the potential to reduce the need for refrigeration during transport and storage, which would result in substantial energy savings. In the study of Li et al., (2017) results showed that the postharvest life, as determined by consumer acceptance criteria of yellowing, increased as the temperature and ethylene concentration decreased. They recommended a storage temperature of about $10^{\circ} \mathrm{C}$ for pak choi, broccoli, and mint and about $18^{\circ} \mathrm{C}$ for green bean.

Understanding the genetic mechanisms underlying processes which control storage life and quality requires studies such as those of $\mathrm{Li}$ et al (2010) which identified the effects of exogenous application of ethylene which reduced fruit firmness and soluble solids content, increased activity of superoxide dismutase (SOD), catalase (CAD) and ascorbate peroxidases (APX) and respiratory rate and upregulated PpETR2 but had no effect on PpETR3. By comparison 1-MCP upregulated PpETR3 and reduced the expression of PpETR2. Consequently, application of ethylene could be used to increase the rate of ripening while 1MCP could be used to slow ripening as required.

Research evaluating storage conditions was, and is, of immediate industrial interest since it permits more flexible harvesting windows and evens the flow of produce into supply chains. Initially, studies focussed on top fruit but extended into vegetables soon afterwards. Manipulating gaseous atmospheres and reducing temperatures for both crop groups resulted in longer storage periods and improved quality afterwards. Reducing wastage caused by pathogens and adverse environments increased the value of storage still further. Understanding the implications of climatrics, production, control of ethylene formation, reducing chlorosis and boosting as appropriate sugar or acid concentrations raised still further the value of storage. These developments paired with more sophistication storage technologies are some of the largest contributions of horticultural science for industrial practice. 


\section{Environment and society}

Horticultural science was one of the earliest disciplines which recognised the importance of sustainably minimising the impact of crop production on diminishing natural resources, mitigating climate change and the benefits of plants for human welfare and wellbeing. Soil conservation has been an integral element in this and found early voice in the use of cover crops protecting soil integrity. Using summer cover crops for fruit plantations showed that they are more likely to compete with the trees than those sown in autumn and spring (Rogers \& Raptppoulos, 1946). All cover crops increased the soil organic matter, there was some association with increased yields but no effects on tree growth. Use of winter oats and winter tares or spring broad red clover was recommended at East Malling Research Station (NIABEMR) where cover crops were less likely to check tree growth compared with short term leys or permanent swards. This approach also requires knowledge of the effects of aeration and soil compaction on the growth for example of the carrot (Olymbios \& Shwabe, 1977). Growing carrots in compacted soil reduced root extension and resulted in stunted foliage. There is now worldwide involvement in such studies, as typified by South Korean work, looking at the effects of hairy vetch, rye and alternating cultivation of rye and vetch cover crops on soil nutrient content (Lee, et al 2014). Leguminous cover crops (hairy vetch) are valuable for increasing soil health and decreasing its bulk density, raising nitrogen-use efficiency, adding to farm incomes and reducing soil nitrogen losses compared with conventional husbandry methods.

Over the past 100 years research and crop production has gone full circle from sustainably traditional techniques through exploitation and back to acknowledging the importance of conserving natural capital. More critical, analytical research into successful horticultural practices which benefit the natural environment, reduce the rates of climate change and 
biodiversity loss and increase soil health is urgently needed and would be eminently suitable for publication in JHSB.

Currently, the Journal receives only a modest number of papers identifying the value of plants for human welfare and wellbeing. A notable exception is a study of potted plant and growth media interacting for removal of volatiles from indoor air (Wood et al., 2002). Potted plants are biofilters which remove volatile organic compounds by virtue of the activities of their root microbes, the volatiles tested were benzene and $n$-hexane both commonly found aerial pollutants. Plants are "rapid response" air cleaning filters. These topics linked with the direct benefits of increasing consumption of fruit and vegetables which diminishes the onset of human diseases of affluence are also very well suited for publication in JHSB.

\section{Conclusions}

This review follows the development of horticultural science as published in JHSB for the past century and links discoveries with industrial change and innovation. There is no attempt in this review at in depth analyses of specific research topics, these are more than adequately covered elsewhere in issues of JHSB during its Centenary Year. Over 100 years fruit, vegetable and flower production has moved from small often family-based enterprises into fewer but larger multimillion-pound businesses. This reflects the change in horticultural science itself from an observational and descriptive process into a quantitative, rational, hypothesis-driven, statistically rigorous discipline utilising knowledge and techniques drawn from the basic biological, chemical, physical and mathematical sciences. The advent of molecular biology in particular provides horticultural science with the means for understanding and developing increasingly sophisticated plant systems. These systems will offer the sustainable crop production strategies needed by a world facing the impact of problems such as global climate 
change, population expansion, soil degeneration, human health decline and biodiversity collapse.

The evolution of industries embracing flower production based on photoperiodic control of flowering, container and containerised trees and shrubs production and sale, orchard, plantation, protected and field vegetable and ornamental intensification through understandings of: genetic compatibilities, nutrition, crop geometry, manipulation of competition, protected environment control and prescriptive, precision growing; contributions to plant breeding especially pest and pathogen control and the development of micropropagation industry all rest on discoveries in horticultural science. In his review of the first fifty volumes of JHSB Professor Hudson (Hudson, 1977) predicted that horticultural science would thrive and change over the following half century. His prediction is amply borne out by the findings contained in this review and with respect, it is suggested that change will be even more substantial and rapid in the forthcoming fifty and one-hundred years. JHSB will, however, continue reporting the innovative horticultural science and supporting industrial progress as predicted by Edward Bunyard, its founder (Dixon, 2019).

\section{References}

Adams P \& Ho L C (1992) The susceptibility of modern tomato cultivars to blossom-end rot in relation to salinity. Journal of Horticultural Science and Biotechnology 67, 827-839.

Amos, J., Hatton, R G ., Hoblyn T N. Knight R C (1930). The effect of scion on root iii stemworked apples. Journal of Horticultural Science and Biotechnology 8, 248-258.

Anon (2017). Nutrient Management Guide (RB209). Agriculture and Horticulture Development Board (AHDB), Stoneleigh Park, Warwickshire. 
Anon (1919) The patenting of new fruits Journal of Horticultural Science and Biotechnology $1,50-53$

Atkinson C J., Taylor L \& Taylor J M (1996). The influence of temperature and water supply on apple fruit growth and the development of orchard - grown trees. Journal of Horticultural Science and Biotechnology 77, 691-703.

Bakker J C., Welles G W H., \& Uffelen J A M van (1987). The effects of day and night humidity on yield and quality of glasshouse cucumbers. Journal of Horticultural Science and Biotechnology 62, 363-370.

Barker J \& Wallace E R (1946) Distribution of temperatures in potato clamps and their influence on sprouting and sugar content. Journal of Horticultural Science and Biotechnology $22,189-196$

Beresford S W \& Jackson A A (1961). The nutrition of garden beet in relation to seed production. Journal of Horticultural Science and Biotechnology 36, 153-159.

Boon, J an der (1980). Prediction and control of bitter pit in apples. II. Control by summer pruning, fruit thinning, delayed harvest and soil calcium dressings. Journal of Horticultural Science and Biotechnology 55, 313-321.

Boxus P H (1974) The production of strawberry plants by in vitro micro-propagation. Journal of Horticultural Science and Biotechnology 49, 209-210.

Brewster J L (1982) Flower and seed production in overwintered cultivars of bulb onions. 1. Effects of different raising environments, temperatures and daylengths. Journal of Horticultural Science and Biotechnology 57, 93-101.

Brown W (1936) On the Botrytis disease of lettuce, with special reference to its control Journal of Horticultural Science and Biotechnology 13, 247-269. 
Bunt A C (1966) An examination of factors contributing to $\mathrm{pH}$ of the John Innes composts Journal of Horticultural Science and Biotechnology 31, 268-271.

Bunyard E A (1919) The history of the Paradise stocks. Journal of Horticultural Science and Biotechnology 1, 166-176.;

Cameron R W F \& Dixon G R (1997). Air temperature, humidity and rooting volume affecting freezing injury to Rhododendron and other perennials. Journal of Horticultural Science and Biotechnology 72, 653-662.

Chacko E K., Reddy Y T N., Ananthanarayanan T V (1982) Studies on the relationship between leaf number and fruit development in mango (Mangifera indica L.) Journal of Horticultural Science and Biotechnology 57, 483-492.

Chambers, J (1961) The production and maintenance of virus-free raspberry plants. Journal of Horticultural Science and Biotechnology 36, 48-64.

Choi C., Wersma P A., Toivonen P. \& Kappel F. (2002). Fruit growth, firmness and cell hydrolytic enzyme activity during development of sweet cherry fruit treated with gibberellic acid $\left(\mathrm{GA}_{3}\right)$ Journal of Horticultural Science and Biotechnology 77, 616-621.

Chung B (1982). Effects of plant density on the maturity and once-over harvest yields of broccoli. Journal of Horticultural Science and Biotechnology 57, 366-372.

Chungwongse J., Chungwongse C. Black L \& Hanson P (2002). Molecular mapping of the Ph3 gene for late blight resistance in tomato. Journal of Horticultural Science and Biotechnology $77,281-286$.

Cleaver T J., Greenwood D J., Whitwell J D., \& Wood M B (1971). Nitrogen and potassium fertiliser requirements of Brussels sprouts. Journal of Horticultural Science and Biotechnology 46, 17-31. 
Cockshull K E,. Graves C J., Cave C RJ (1992). The influence of shading on yield of glasshouse tomatoes. Journal of Horticultural Science and Biotechnology 67, 11-24.

Cockshull K E., \& Horridge J S (1977). Apical dominance and flower initiation in the rose. Journal of Horticultural Science and Biotechnology 52, 421-427.

Cooper A J (1961) Observations on flowering in glasshouse tomato plants considered in relation to light duration and plant age. Journal of Horticultural Science and Biotechnology 36, $102-115$.

Corke A T K (1974). The prospect for biotherapy in trees infected by silver leaf. Journal of Horticultural Science and Biotechnology 49, 391-394.

Crane M B (1922). Reports on tests of self-sterility and cross-incompatibility in plums, cherries and apples at the John Innes Horticultural Institution Journal of Horticultural Science and Biotechnology 3, 67-84.

Crane M B \& Lawrence W J C (1928). Genetical and cytological aspects of incompatibility and sterility in cultivated fruits. Journal of Horticultural Science and Biotechnology 7, 276301.

Crane M B \& Lewis D (1941). Genetical studies in pears ii a classification of cultivated varieties Journal of Horticultural Science and Biotechnology 18, 52-60.

Cripps J E L(1971). The influence of soil moisture on apple root growth and root:shoot ratios. Journal of Horticultural Science and Biotechnology 46, 121-130.

Curry E A (1997). Temperatures for optimum anthocyanin accumulation in apple tissue. Journal of Horticultural Science and Biotechnology 72 , 723-729. 
Daymond A J., Wheeler T R, Hadley P., Ellis R H. \& Morison J I L (1997). The growth, development and yield of onion (Allium cepa $\mathrm{L}$.) in response to temperature and $\mathrm{CO}_{2}$. Journal of Horticultural Science and Biotechnology 72, 136-145.

Dixon, G. R. (2019). The origins and development of the Journal of Horticultural Science and Biotechnology (JHSB) 1919-2019. Journal of Horticultural Science and Biotechnology (in press).

Dodds K S \& Cope F W (1961). Field experiments with clonal cacao. Journal of Horticultural Science and Biotechnology 26, 249-260.

Drew R L K (1982). The effects of irrigation and shelter from wind on emergence of carrot and cabbage seedlings. Journal of Horticultural Science and Biotechnology 67, 216-219.

Du L J., Qi Y Y, Liu Y L., Tian F F., Zhou Q. \& Wang W J (2014) Embryogenic culture of lily (Lilium spp.): optimising callus initiation, maintenance and plantlet regeneration. Journal of Horticultural Science and Biotechnology 89, 159-166.

Emden H F van \& Hadley P (2011) Plastic films for polytunnels can prolong the effective residual life of cypermethrin to over 6 months. Journal of Horticultural Science and Biotechnology 86, 196-200.

Famiani F., Baldicchi A., Battistelli A., Moscatello S \& Walker R P (2009). Soluble sugar and organic acid contents and the occurrence and potential role of phosphoenolpyruvate carboxykinase (PEPCK) in gooseberry (Ribes grossularia L.). Journal of Horticultural Science and Biotechnology 84, 249-254.

Fenlon, J S., Jones SK., Hanks G R \& Langton F A (1990). Bulb yields from narcissus chipping and twin-scaling. Journal of Horticultural Science and Biotechnology 65, 441-150. 
Fernandez F., Vincente-Sanchez J., Maestrre-Valero J F., Bernabe A J., Nicolas, E., Pedrero F \& Alarcon J J (2014). Physiological and growth responses of young tomato seedlings to dripirrigation containing two low doses of the arbuscular mycorrhizal fungus Glomus iranicum var. tenihypharum sp. nova . Journal of Horticultural Science and Biotechnology 89, 679-685.

Fernandez V., Orera I., Abadia A. \& Abadia A (2009). Foliar iron-fertilisation of fruit trees: present knowledge and future perspectives - a review. Journal of Horticultural Science and Biotechnology 84, 1-6.

Finch-Savage, W E (1984). The effects of fluid drilling germinating seeds on the emergence and subsequent growth of carrots in the field. Journal of Horticultural Science and Biotechnology 59, 411-417.

Flegg, P B (1961). The natural accumulation of soluble salts in the casing layer of mushroom beds. Journal of Horticultural Science and Biotechnology 36, 139-144.

Ford K L., Henricot B., Baumgartner K., Bailey A M. \& Foster G D (2017) A faster inoculation assay for Armillaria using herbaceous plants. Journal of Horticultural Science and Biotechnology 92, 39-47.

Gane R (1936). The formation of ethylene by plant tissues and its significance in the ripening of fruits. Journal of Horticultural Science and Biotechnology 13, 361-368.

Geeson J D., Browne K M. \& Everson H P (1989) Long term refrigerated storage of swedes. Journal of Horticultural Science and Biotechnology 64, 479-483.

Germana, M A., Wang Y Y., Barbagallo M G., Iannolino G \& Crescimanno, F G (1994). Recovery of haploid and diploid plantlets from anther culture of Citrus clementina Hort. ex Tan and Citru reticulata Blanco. Journal of Horticultural Science and Biotechnology 69, 473480. 
Goodlass G., Rahn C., Shepherd M A., Chalmers A G. \& Seeney F (1997). The nitrogen requirement of vegetables: comparisons of yield response models and recommendation systems. Journal of Horticultural Science and Biotechnology 72, 239-264.

Gordon S C., Woodford J A T \& Birch A N E. (1997). Arthropod pests of Rubus in Europe: pest status, current and future control strategies. Journal of Horticultural Science and Biotechnology 72, 831-862.

Gotme T P., Cullen D W., Graham J., Hedley P E., Smith K., Anderson L. Petersen K K (2014). Effect of short-term exposure to high-temperature on total gene expression in the leaves of four raspberry (Rubus idaeus L.) cultivars. Journal of Horticultural Science and Biotechnology 89, $532-541$.

Grange R I \& Hand D W (1987). A review of the effects of atmospheric humidity on the growth of horticultural crops. Journal of Horticultural Science and Biotechnology 62, 125-134.

Gray D. (1978). Comparison of fluid drilling and establishment techniques on seedling emergence and crop uniformity in lettuce. Journal of Horticultural Science and Biotechnology $53,23-30$

Hanks G R (1996). Variation in he growth and development of narcissus in relation to meteorological and related factors. Journal of Horticultural Science and Biotechnology 71, $517-532$

Harris D C (1991). The Phytophthora diseases of apple. Journal of Horticultural Science and Biotechnology 66, 513-540.

Hatton R G (1919) Black current varieties - a method of classification. Journal of Horticultural Science and Biotechnology 1, 65-80. 
Hatton R G (1920). Results of researches on fruit tree stocks at East Malling. Journal of Horticultural Science and Biotechnology 2, 1-9

Hatton R G (1936). Apple rootstock studies effect of layered stocks upon the vigour and cropping of certain scions. Journal of Horticultural Science and Biotechnology 13, 293-360.

Herrero J (1951) Studies of compatible and incompatible graft combinations with special reference to hardy fruit trees. Journal of Horticultural Science and Biotechnology 26, 186-237. Heydecker W (1966). Establishment of seedlings in the field i. the influence of sowing depth on seedling emergence. Journal of Horticultural Science and Biotechnology 31, 76-88.

Hickman C J (1941) The red core disease of strawberry caused by Phytophthora fragariae n.sp. Journal of Horticultural Science and Biotechnology 18, 89-118.

Hilton H W., Clifford S C., Wurr D C E., Burton K S (2009). The influence of agronomic factors on he visual quality of field-grown, minimally-processed lettuce. Journal of Horticultural Science and Biotechnology 84, 193-198.

Hoblyn T N., (1941). Manurial trials with apple trees at East Malling 1920-39. Journal of Horticultural Science and Biotechnology 18, 325-343.

Hobson G E (1981) The short term storage of tomato fruit. Journal of Horticultural Science and Biotechnology 56, 363-368.

Hole C C ., Drew R L K. \& Gray D (2002). Skin colour and quality of onion cultivars given different nitrogen and irrigation treatments. Journal of Horticultural Science and Biotechnology 77, 191-199.

Hudson, J P (1977). The journal of horticultural science - the first fifty volumes. Journal of Horticultural Science and Biotechnology 52, 1-8. 
Huguet J -G., Li, S H., Lorendeau J -Y. \& Pelloux G. (1992). Specific micromorphometric reactions of fruit trees to water stress and irrigation scheduling automation. Journal of Horticultural Science and Biotechnology 67, 631-640

Irving D E \& Drost J H (1987). Effects of water deficit on vegetative growth, fruit growth and fruit quality in Co's Orange Pippin apple. Journal of Horticultural Science and Biotechnology $62,427-432$

Iwanami H., Morlya, S. \& Abe, K. (2009). Relationships between sap flow, hydraulic conductivity and the anatomical characteristics of stems and roots in apple rootstocks of different vigour. Journal of Horticultural Science and Biotechnology 84, 632-638.

Jackson J E \& Sharples R O (1971). The influence of shade and within-tree position on apple fruit size, colour and storage quality. Journal of Horticultural Science and Biotechnology 46, 277-287.

Jennings D L \& Dale A A (1982). Variation in the growth habit of red raspberries with particular reference to cane height and node production. Journal of Horticultural Science and Biotechnology 67, 197-204.

Johnson D S, Marks M J \& Pearson K (1987) Storage quality of Cox's Orange Pippin apples in relation to fruit mineral composition during development Journal of Horticultural Science and Biotechnology 62, 17-26.

Jones O P., Hopgood M E. O'Farrell D (1977). Propagation in vitro of M. 26 apple rootstocks. Journal of Horticultural Science and Biotechnology 52, 235-238.

Jorquera-Fontena E., Genard M \& Franck N (2017). Analysis of blueberry (Vaccinium corymbosum L. ) fruit water dynamics during growth using an ecophysiological model. Journal of Horticultural Science and Biotechnology 92, 646-659. 
Kenny G J \& Shao J (1992) An assessment of a latitude-temperature index for predicting climate suitability for grapes in Europe. Journal of Horticultural Science and Biotechnology $67,239-246$.

Khalil S., Hultberg M. \& Alsanius B W (2009) Effects of growing medium on the interaction between biocontrol agents and tomato root pathogens in a closed hydroponic system. Journal of Horticultural Science and Biotechnology 84, 489-494.

Kidd F \& West C (1930) The gas storage of Fruit ii optimum temperatures and atmospheres Journal of Horticultural Science and Biotechnology 8, 67-77

Kidd, F., West C., Griffiths, D. G. \& Potter, N. A. (1951) Metabolism of malic acid in apples. Journal of Horticultural Science and Biotechnology 26, 163-168.

Knight R C (1930). Some effects of pruning "leaders" and of the absence of "laterals" on the rate of growth of stems of apple and plum. Journal of Horticultural Science and Biotechnology 8, 93-103.

Lee, S_M., Yun H-B., Gu M., Sung J-K., Lee N-B-M., Cho J-R., Jung S-K. \& Choi H-S (2014). Effects of hairy vetch, rye and alternating cultivation of rye-vetch cover crops on soil nutrient concentrations and the production of red pepper (Capsicum annuum L). Journal of Horticultural Science and Biotechnology 89, 245-252.

Li T., Niki T., Nishijima T., Douzono M., Koshioka M \& Hisamatsu T (2002) Roles of CmFL, CmAFL1 and CmSOCl in the transition from vegetative to reproductive growth in Chrysanthemum morifolium Ramat. Journal of Horticultural Science and Biotechnology 84, 447-463. 
Li Y., Wills R BH \& Golding J B (2017). Interaction of ethylene concentration and storage temperature on post-harvest life of the green vegetables pak choi, broccoli, mint and green bean. Journal of Horticultural Science and Biotechnology 92, 288-293.

Li, Z Q., Qiao, L S., Tong, Z G., Zhou, J. \& Zhang Z. (2010). Effect of ethylene and 1-MCO on the post-harvest physiology and on the expression of the ethylene receptor genes PpETR3 and PpERS2 in pear (Pyrus pyrifolia Nakai 'Kikusui') fruit. Journal of Horticultural Science and Biotechnology 85,71-77.

Lockwood G (1977). Studies on the effects of cross-incompatibility on the cropping of cocoa in Ghana. Journal of Horticultural Science and Biotechnology 62, 113-126.

Luckwill, L. C. (1953). Studies of fruit development in relation to plant hormones.1. hormone production by developing apple seed in relation to fruit drop. Journal of Horticultural Science and Biotechnology 28, 14-24.

Marsh R W \& Walker M (1932). The scab fungus (Venturia injequalis) on apple shoots). Journal of Horticultural Science and Biotechnology 10, 71-90.

Massee A M (1930). The tarsonemid mite of strawberry. Journal of Horticultural Science and Biotechnology 8, 305-308.

Matsumoto, S., Furusawa Y., Komatsu H. \& Soejima J. (2003). S-allele genotypes of apple pollenizers, cultivars and lineages including those resistant to scab. Journal of Horticultural Science and Biotechnology 78, 634-637.

Mazri, M A (2014). Effects of growth regulators and carbon source on shoot proliferation and regeneration in date palm (Phoenix dactylifera L.) '16 Bis' . Journal of Horticultural Science and Biotechnology 89, 415-422. 
Miles H W (1921). The role of crab apple trees and old cider trees in harbouring certain insect pests of fruit plantations. Journal of Horticultural Science and Biotechnology 2, 274-77.

Miles H W (1922). Control of apple blossom weevil. Journal of Horticultural Science and Biotechnology 3, 54-61.

Moore M H (1930). The incidence and control of apple scab and apple mildew at East Malling. Journal of Horticultural Science and Biotechnology 8, 229-247.

MurashigeT \& Skoog F (1962). A revised medium for rapid bioassays with tobacco tissue cultures. Physiologia Plantarum 15, 471-497.

Nabeshima, T., Hosokawa M., Yano S., Ohishi K \& Doi M (2014) Evaluation of chrysanthemum stunt viroid (CSVd) infection in newly - expanded leaves from CSVdinoculated shoot apical meristems as a method of screening for CSVd-resistant chrysanthemum cultivars. Journal of Horticultural Science and Biotechnology 89, 29-34.

Nelder J A \& Moss N (1956). Spacing of lettuce in heated glasshouses Journal of Horticultural Science and Biotechnology 31, 177-187

Nichols A A ., Davies A P., King K., Winter E J., Blackwell F L \& Blackwell C (1971). Contamination of lettuce irrigated with sewage effluent. Journal of Horticultural Science and Biotechnology 46, 425-433.

Olle M \& Willaims I H. (2013). Effective microorganisms and their influence on vegetable production - a review. Journal of Horticultural Science and Biotechnology 88, 380-386.

Olymbios C M \& Shwabe W W (1977) Effects of aeration and soil compaction on growth of the carrot, Daucus carota L Journal of Horticultural Science and Biotechnology 62, 486-500. 
Oran S \& Fattash I (2005) In vitro propagation of an endangered medicinal bulbous plant Sternbergia clusiana Ker-Gawler (Amaryllidaceae). Journal of Horticultural Science and Biotechnology 80, 399-402.

Orton W A (1914). Potato wilt, leaf roll and related diseases. United States Department of Agriculture Bulletin no 64.

Oren-Shamir M \& Levi-Nissim A (1997) Temperature effects on the leaf pigmentation of Cotinus coggygria 'Royal Purple'. Journal of Horticultural Science and Biotechnology 72, 426-432.

Osborne D J \& Wain R L (1951) Studies on plant growth regulating substances ii synthetic compounds inducing morphogenic responses in the tomato plant. Journal of Horticultural Science and Biotechnology 26, 60-74.

Osborne D J., Wain R L \& Walker R D ( 1952) Studies on plant growth-regulating substances: IV The activity of certain aryloxy acids for inducing rooting and for tomato setting. Journal of Horticultural Science and Biotechnology 27, 44-52.

Pethybridge G H (1940). History and connotation of the term Blattrollkheit (leaf roll disease) as applied to certain potato diseases. Phytopathologische Zietschrift 12, 283-291.

Porat, R., Daus A., Weiss B., Cohen L. \& Droby S (2002). Effects of combining hot water, sodium bicarbonate and biocontrol on postharvest decay of citrus fruit. Journal of Horticultural Science and Biotechnology 77, 441-446

Preston A P (1966). Apple rootstock studies: fifteen year's results with Malling-Merton clones. Journal of Horticultural Science and Biotechnology 41, 349-360.

Pristijono P., Papoutsis K., Scarlett C J., Bowyer M C ., Vuong Q V., Stathopoulos C E \& Golding J B (2017). Post-harvest UV-C treatment combined with 1-methycyclopropene 91- 
MCP) followed by storage in continuous low-level ethylene atmosphere, improves the quality of tomatoes. Journal of Horticultural Science and Biotechnology 92, 621-629.

Quorin M. \& Lepoivre P (1977). Improved media for invitro culture of Prunus sp. Acta Horticulturae, 78, 437-442.

Raji R \& Siril E A (2016). Cloning the Ceylon olive (Elaeocarpus serratus L.) using conventional methods. Journal of Horticultural Science and Biotechnology 91, 292-298.

Reeves, J., Fellows J R., Phelps K., Wurr D C E (2001). Development and validation of a model describing the curd induction of winter cauliflower. Journal of Horticultural Science and Biotechnology 76, 714-720.

Rogers W S \& Raptppoulos (1946) Cover crops for fruit plantations Journal of Horticultural Science and Biotechnology 22, 92-102

Rohwer, C L \& Erwin J E (2008). Horticultural applications of jasmonates. Journal of Horticultural Science and Biotechnology 83, 283-304.

Salmond, E S (1906). Apple scab or black spot. Gardeners' Chronicle 40, 21-23

Salmond E S (1908) Apple scab or black spot. Journal of the Board of Agriculture. 105,182195.

Salter P J (1961) The irrigation of early summer cauliflower in relation to stage of growth, plant spacing and nitrogen level. Journal of Horticultural Science and Biotechnology 36, 241263.

Salter, P J (1976). Comparative studies of different production systems for early crops of bulb onions. Journal of Horticultural Science and Biotechnology 51, 329-339. 
Selman I W (1946). The localization of tobacco mosaic virus in tomato fruits. Journal of Horticultural Science and Biotechnology 22, 226-230.

Selman I W (1947b). Resistance to mosaic infection in the tomato in relation to soil conditions. Journal of Horticultural Science and Biotechnology 23, 71-79.

Selman, I W (1947a). The growth of the plant in relation to the incidence of virus infection.A survey of the literature. Journal of Horticultural Science and Biotechnology 23, 50-62.

Selvi D T \& Saraswathy S (2018) Seed viability, seed deterioration and seed quality improvements in stored onion seeds: a review. Journal of Horticultural Science and Biotechnology 93, 1-7.

Semancik J S., Rakowski A G., Bash J A., Gumpf D J (1997). Application oof selected viroids for dwarfing and enhancement of production of 'Valencia' orange. Journal of Horticultural Science and Biotechnology 72, 663-670.

Sharples, R O (1968). Fruit thinning effects on the development and storage quality of Cox's Orange Pippin apple fruits. Journal of Horticultural Science and Biotechnology 43, 359-371.

Shivashankar S., Sumathi M., Rao V K (2017) Uneven ripening in 'Bangalore blue' grape (Vitis vinifera $\mathrm{x}$ Vitis labrusca) berries in India is linked to seed viability. Journal of Horticultural Science and Biotechnology 92, 113-119.

Singh, N., Pal A K., Meena B., Roy R K., Tamta S., \& Rana T S (2017) Development of ISSRand RAPD-derived SCAR markers for identification of Gladiolus germplasm. Journal of Horticultural Science and Biotechnology 92, 677-682.

Smith W H (1941) The storage of broccoli and cauliflower. Journal of Horticultural Science and Biotechnology 18, 287-293. 
Sonsteby A \& Heide O M (2017). Flowering performance and yield of established and recent strawberry cultivars (Fragaria $\mathrm{x}$ ananassa) as affected by raising temperature and photoperiod Journal of Horticultural Science and Biotechnology 92, 367-375

Southwick, S M., Ingels, C., Hansen R. \& Glozer K (2004). The effects of Apogee ® on shoot growth, secondary flowering, fire blight, fruit quality, yield and return bloom in 'Bartlett' pear growing in California. Journal of Horticultural Science and Biotechnology 79, 380-389.

Stoughton RH (1941). The nutrition of Dutch iris: an experiment in factorial design Journal of Horticultural Science and Biotechnology 18, 297-306.

Sun, Q R., Sun H Y., Bell R L., Li, LG., Xin, L., Tao, J H \& Li Q (2014). Optimisation of the media for in vitro shoot proliferation and root induction in three new cold hardy and dwarfing or semi-dwarfing clonal apple rootstocks. Journal of Horticultural Science and Biotechnology 89, 381-388.

Sutton, I. (1919) Report of tests of self-sterility in plums, cherries and apples at the John Innes Horticultural Institution. Journal of Horticultural Science and Biotechnology, 1, 1-19

Sutton, M W., Robinson D L., Dixon G R \& Wilson F (1988). The growth and yield of virustested and visually healthy Narcissus stocks from different localities. Journal of Horticultural Science and Biotechnology 63, 479-487.

Theobald F V 1920 The woolly aphid of apple and elm, part 1. Journal of Horticultural Science and Biotechnology 2, 73-91.

Theobald F V (1921) The woolly aphid of apple and elm part 2 (treatment) Journal of Horticultural Science and Biotechnology 2, 199-205.

Thompson, R B., Voogt W., Incrocci L., Fink M. \& Neve S. de (2018) Strategies for optimal fertiliser management of vegetable crops in Europe. Acta Horticulturae no 1192, 129-140. 
Toivonen P M (1992). The reduction of browning in parsnips. Journal of Horticultural Science and Biotechnology 67, 547-551.

Torre-Gonzales A de la., Montesinos-Pereira D., Romero, L., Blasco B \& Ruiz J (2018) Analysis of metabolic and nutritional biomarkers in Brassica oleracea L cv Bronco under alkaline stress Journal of Horticultural Science and Biotechnology 93, 279-288;

Trout S A (1930). Experiments on the storage of pears in artificial atmospheres Journal of Horticultural Science and Biotechnology 8, 78-90.

Tucker W G (1981). Observations on the storage performance of individual beetroots. Journal of Horticultural Science and Biotechnology 56, 97-98.

Turner A D (1924) Trial of spring cabbage (autumn sown) (1922-1923) Journal of Horticultural Science and Biotechnology 3, 179-182

Vince D., Clarke M G., Ruff H R \& Stoughton R H (1966). Studies on the effects of light quality on the growth and development of plants : I apparatus for the growing of plants unde controlled light and temperature conditions. Journal of Horticultural Science and Biotechnology 31, 8-16.

Voltz, R. K., Ferguson, I. B., Bowen, J. H. \& Watkins, C. B. (1993). Crop load effects on fruit mineral nutrition, maturity, fruiting and tree growth of Cox's Orange Pippin apple. Journal of Horticultural Science and Biotechnology 68, 127-137.

Vyvyan M C (1946) Experiments with growth substances for reduction of pre-harvest drop of fruit. Journal of Horticultural Science and Biotechnology 22, 11 -37.

Wallace T (1930) 8(1) 23-45 Experiments on the manuring of fruit trees iii the effects of deficiencies of potassium, calcium and magnesium respectively on the contents of these 
element and of phosphorus in the shoot and trunk regions of apple trees. Journal of Horticultural Science and Biotechnology 8, 23-45.

Wallace $\mathrm{T}$ (1935) Investigations on chlorosis of fruit trees $\mathrm{v}$. the control of lime induced chlorosis by injection of iron salts. Journal of Horticultural Science and Biotechnology 13, 5467.

Wallace T \& Hewett E J (1946). Studies in iron deficiency of crops i. problems of iron deficiency and the interrelationships of mineral elements in iron nutrition. Journal of Horticultural Science and Biotechnology 22, 153-161.

Wallace T \& Spinks G T (1941) A long period field experiment on the manuring of apple trees. Journal of Horticultural Science and Biotechnology 18, 182-192.

Wang, Q., Hou x 1., Geng J F., Chang Y., Ban Q Y., Zou J W \& Barker G C (2010). Quantitative trait loci for photosynthetic pigment concentration in a doubled - haploid population of Pak Choi (Brassica rapa spp. chinensis var. communis Tsen \& Lee). Journal of Horticultural Science and Biotechnology 86, 421-426.

Warne L G G (1961). Spacing experiments on vegetables i. the effect of thinning distances on earliness in globe beet and carrots in Cheshire 1948. Journal of Horticultural Science and Biotechnology 26, 79-83

Watt, K., Graham J., Gordon S C., Woodhead M \& McNicol R J (1999) Current and future transgenic control strategies to vine weevil and other insect resistance in strawberry. Journal of Horticultural Science and Biotechnology 74, 409-421.

Wood RA., Orwell RL., Tarran J., Torpy F \& Burchett M (2002). Potted plant /growth media interactions for removal of volatiles from indoor air Journal of Horticultural Science and Biotechnology 77, 120-129. 
Wu S-B. Collins G \& Sedgley M (2002) Sexual compatibility within and between olive cultivars Journal of Horticultural Science and Biotechnology 77, 666-673.

Wurr D C E., Fellows J R., Hambidge A J \& Fuller M P (1999). Growth, development and bolting of early leeks in the UK. Journal of Horticultural Science and Biotechnology 74, 140146.

Wurr D C E., Fellows J R., Hiron R W P, Antill DN \& Hannd D J (1992). The development and evaluation of techniques to predict when to harvest iceberg lettuce heads. Journal of Horticultural Science and Biotechnology 67, 386-393.

Xiao F., Yang Z Q \& Lee K W (2017). Photosynthetic and physiological responses to high temperatures in grapevine (Vitis vinifera L) leaves during the seedling stage. Journal of Horticultural Science and Biotechnology 92, 1-10

Yu, X., Wang H T., Liu Y., Liang C Y \& Li W L (2013). In vitro induction of chromosomedoubling in cultured shoots of three cultivars of mint (Mentha canadensis L.) treated with colchicine. Journal of Horticultural Science and Biotechnology 88, 306-312.

Zanf Q., Jiao Y., Guo X., Zhuge F.,Yeh K \& Lin x (2017) Callus induction and plant regeneration from lateral shoots of herbaceous bamboo Mniochloa abersend. Journal of Horticultural Science and Biotechnology 92, 168-174. 